\title{
Correspondence
}

\section{Detection of main channel thickness from radar data at Jakobshavn Isbræ, Greenland}

Glaciologists seek the mass balance of the polar ice sheets to understand the contribution of the ice masses to the rising global sea level (Asrar and Dozier, 1994). One method of mass-balance monitoring requires knowledge of the changing input and output mass fluxes from the ice sheets. The outflow from ice streams and fast-flowing outlet glaciers is a major factor influencing the total mass balance of ice sheets.

Whereas ice-sheet surface dynamics can be inferred from space-borne remote-sensing data (Joughin and others, 1996), ice thickness remains a major unknown for a number of outlet glaciers; moreover, ice thickness is a critical term in the mass continuity equation. In particular, ice-thickness data across a glacier (perpendicular to the direction of ice flow) are useful for calculating its ice flux (Rignot and others, 2001). Modern airborne radar depth sounders are having great success in measuring ice thickness over an overwhelming majority of the ice sheets (Bogorodsky and others, 1985; Gogineni and others, 2001). However, modern radars have been challenged at Jakobshavn Isbræ, mainly by signal absorption loss through relatively warm ice or melt conditions and by clutter from the crevassed surfaces (Braaten and others, 2002). Seismic surveys remain a proven method for measuring the ice thickness in heavily crevassed outlet areas such as Jakobshavn Isbræ (Weidick, 1992), but the large-scale application is limited by several factors such as logistics, cost, time and safety.

Jakobshavn Isbræ is the most active glacier in Greenland, with a discharge of up to $50 \mathrm{~km}^{3} \mathrm{a}^{-1}$ of ice Joughin and others, 2004). The glacier's fast-moving surface indicators (e.g. shear margins, crevasse bands and flow stripes) extend from the margin to deep into the ice sheet's interior (Krabill and others, 2000). Because of the scientific interest of fastmoving outlets, several missions using a modern radar ice sounder acquired data from Jakobshavn Isbræ under the NASA Program for Arctic Regional Climate Assessment (PARCA).

PARCA ice-sounding data have been collected in Greenland since 1993 using the University of Kansas ice-sounding radar system on a NASA P-3 aircraft (Gogineni and others, 2001). The ice sounder is a pulse compression radar system that operates at a center frequency of $150 \mathrm{MHz}$. A fourelement dipole array with a $3 \mathrm{~dB}$ beamwidth of $72^{\circ}$ is mounted on each wing of the P-3 aircraft platform. The output power of the transmitter is about $200 \mathrm{~W}$. The coherent system records the in-phase and quadrature components of the radar return signal every $53.3 \mathrm{~ns}$ (about $4.5 \mathrm{~m}$ in ice, assuming a velocity of propagation of $169 \mathrm{~m} \mathrm{ss}^{-1}$ ). During collection of data for this study the radar transmitted 9200 pulses s$^{-1}$, while the aircraft speed was about $130 \mathrm{~m} \mathrm{~s}^{-1}$ at an altitude of about $500 \mathrm{~m}$.

We explored about $38 \mathrm{~km}$ worth of data from the Jakobshavn area (Tee and others, 1999). Figure 1a illustrates the location of the Jakobshavn study site as a box near the western coast of Greenland, and Figure $1 \mathrm{~b}$ shows the flightline. A strong clutter region is present in the radar echogram along the flightline as shown in Figure 1c. The main channel of the Jakobshavn outlet glacier lies in this high-clutter region. The channel width appears to be less than $15 \mathrm{~km}$ (Fig. 1c from about $12 \mathrm{~km}$ to $27 \mathrm{~km}$ ) at this location.

Along-track SAR (synthetic aperture radar) processing of glacial ice-sounding data (Legarsky and others, 2001) has improved the detection of weak bed echoes in parts of Jakobshavn Isbræ (Braaten and others, 2002) and other glaciers (e.g. Peters and others, 2005). SAR processing can improve the signal-to-noise ratio and help reduce alongtrack clutter. At Jakobshavn Isbræ, Braaten and others (2002) detected the main channel $36 \mathrm{~km}$ upstream from our study site with a $1-2 \mathrm{~dB}$ improvement using SAR processing. SAR processing helped reduce the surface clutter from the radar echogram at our study site (Fig. 1e); however, the bottom signature could not be clearly identified. The along-track SAR is suboptimal for the Jakobshavn Isbræ data because it does not account for the presence of strong cross-track surface clutter.

To aid in ice-thickness detection at Jakobshavn Isbræ where SAR processing does not reveal the bottom signature, we developed a processing strategy for the Jakobshavn Isbræ main channel from the radar data at the coordinates $69^{\circ} 05^{\prime} \mathrm{N}, 49^{\circ} 28^{\prime} \mathrm{W}$. To detect signal edges associated with the bedrock, each row in the radar echogram is differenced with the preceding row. Thus, a bedrock signal would have a positive difference followed by a negative difference in depth. However, after differencing, many positive and negative values are present throughout the image in a near-random way as shown in Figure $1 \mathrm{~d}$. A smoothing window ( $230 \mathrm{~m}$ in depth by $20 \mathrm{~m}$ along the flightline) is applied to the image to average the positive and negative differences. The smoothing reduces enough surface clutter to reveal the underlying hyperbolic signatures as shown in Figure 1f. Finally, we applied a threshold to the image to display the positive difference, which is associated with the signal's first return.

We applied the processing to the radar echogram along the flightline from about $13 \mathrm{~km}$ to $26 \mathrm{~km}$ for thickness values greater than $\sim 1200 \mathrm{~m}$. Figure $1 \mathrm{~g}$ illustrates the processed area superimposed on an expanded portion of the flightline. We noticed a near-hyperbolic-looking signature $(>10 \mathrm{~dB}$ signal-to-noise clutter ratio) centered horizontally at about the $20 \mathrm{~km}$ location on the flightline. Upon further examination, we found the signature to be dominated by two closely spaced hyperbolic signatures. To aid visualization, we superimposed a hyperbolic response on Figure $1 \mathrm{~g}$ for each signature, which corresponds to a radar propagation velocity of $169 \mathrm{~m} \mathrm{\mu s}^{-1}$. Hyperbolic signatures are a characteristic of a strong scatterer with the peak associated with the first return, and the remaining signature from the offnadir returns. The fact that the points observed behave as scattering points implies that to either side of this feature the ice must be thicker. We believe the signatures are from a hill near the bottom of the main channel. Thus, the ice-thickness values using a radar propagation velocity of $169 \mathrm{~m} \mathrm{ss}^{-1}$ are found from the peak of the hyperbolic signatures. The ice thickness above the hill ranges from about $2160 \mathrm{~m}$ to $2300 \mathrm{~m}$ $( \pm 230 \mathrm{~m}$ due to smoothing) around the $20 \mathrm{~km}$ location.

Braaten and others (2002) reported ice-thickness measurements from two traverses of Jakobshavn Isbræ. Icethickness values of 2192 and 2014 m were reported for the 

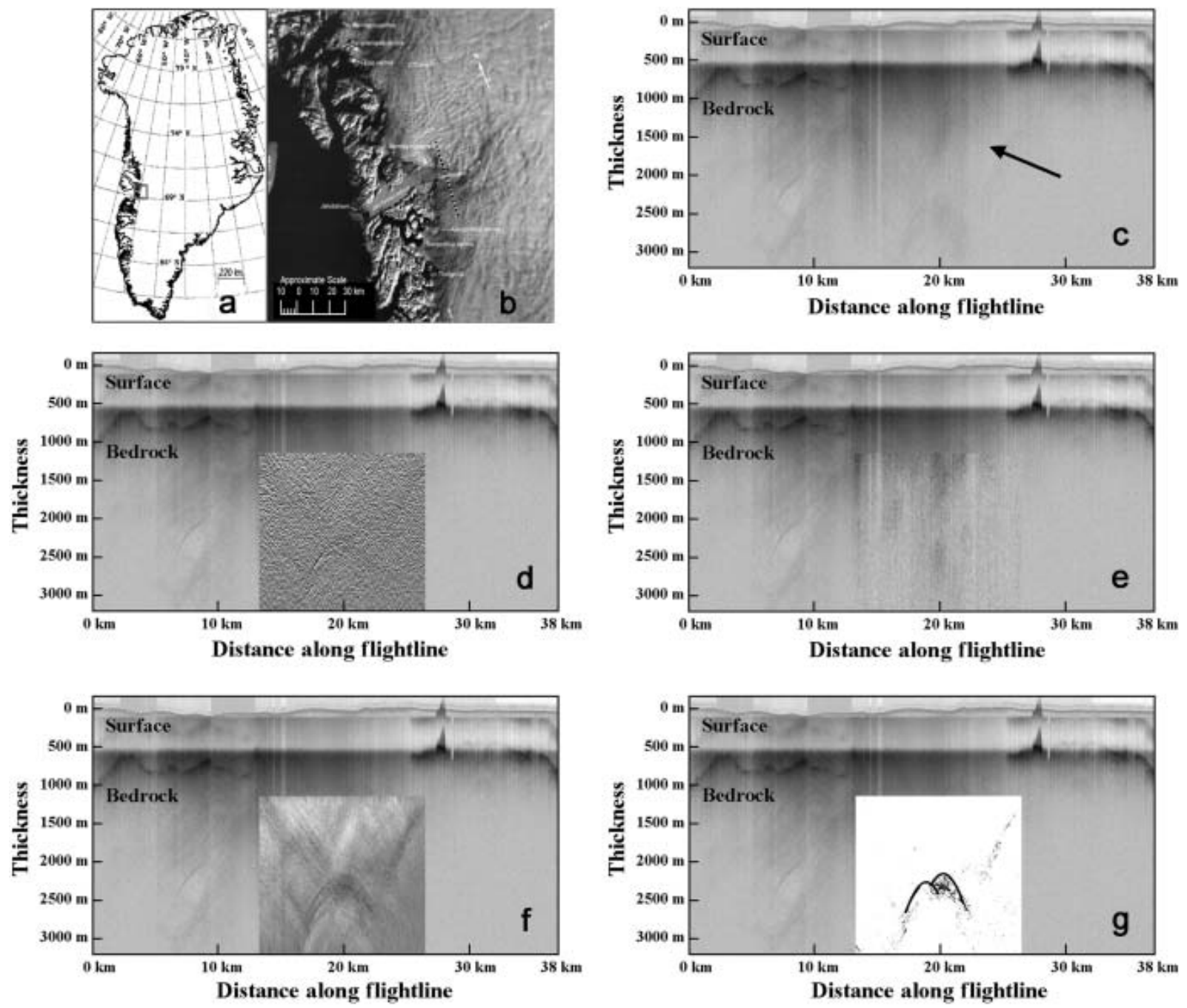

Fig. 1. (a) Greenland map with the Jakobshavn Isbræ study site shown as a box on the western coast. (b) Flightline (dashed line) superimposed on a satellite image of the Jakobshavn region. (c) Radar echogram of ice thickness recorded from a flight over the Jakobshavn main channel. An arrow points to subsurface returns corrupted by strong surface clutter. (d) Image after differencing. (e) Image after SAR processing. (f) Image after smoothing the difference result. (g) After processing, radar echogram of ice thickness recorded from a flight over the Jakobshavn main channel. The hyperbolic-looking signatures are probably from a hill near the bottom of the main channel. The icethickness scale is given for $0 \mathrm{~km}$ on the flightline. For other distances along the flightline the scale should be shifted with the $0 \mathrm{~m}$ thickness always at the ice surface.

thickest portion of the channel, at 36 and $79 \mathrm{~km}$ upstream from our site, respectively. A hill 81 and $85 \mathrm{~m}$ above the deepest portion of the channel is seen for the reported traverses, 36 and $79 \mathrm{~km}$ upstream from our site, respectively. It seems likely that the maximum ice thickness from our site is the ice thickness above the bedrock hill plus an additional $81 \mathrm{~m}$ or more.

A recent map of Greenland ice thickness (Bamber and others, 2001) shows significant discrepancy (about $1400 \mathrm{~m}$ ) at our Jakobshavn Isbræ site. The discrepancy mainly occurs because of interpolation over the main channel areas where ice-thickness data were missing. The discrepancy is not surprising since the ice-thickness map does not include either Braaten and others' (2002) data or our values of the main channel thickness. By including the new ice-thickness data from the main channel, the ice-thickness map can be improved over the Jakobshavn Isbræ region.

We believe the detected signatures are from the Jakobshavn main channel in a location where strong surface clutter masks the unprocessed radar echogram. We observed more than a $10 \mathrm{~dB}$ improvement in the signal-to-clutter ratio after processing. In addition, the processing strategy developed for the Jakobshavn main channel may be beneficial in radar echograms from other locations where clutter signals mask the bedrock return.

\section{ACKNOWLEDGEMENTS}

We thank NASA and the University of Kansas Remote Sensing Laboratory for providing radar data for this research. In addition, we thank the University of Missouri Research Council for their support.

Department of Electrical and Computer Engineering

The University of Missouri-Columbia

Justin LEGARSKY Heng HUANG

349 Engineering Building West,

Columbia, Missouri 65211, USA

E-mail: legarskyj@missouri.edu

10 March 2006 


\section{REFERENCES}

Asrar, G. and J. Dozier. 1994. Eos: science strategy for the Earth Observing System, Woodbury, NY, AIP Press.

Bamber, J.L., R.L. Layberry and S.P. Gogineni. 2001. A new ice thickness and bed data set for the Greenland ice sheet. 1 . Measurement, data reduction, and errors. J. Geophys. Res., 106(D24), 33,773-33,780.

Bogorodsky, V.V., C.R. Bentley and P.E. Gudmandsen. 1985. Radioglaciology, Dordrecht, etc., D. Reidel Publishing Co.

Braaten, D.A., S.P. Gogineni, D. Tammana, S. Namburi, J. Paden and K.K. Gurumoorthy. 2002. Improvement of radar icethickness measurements of Greenland outlet glaciers using SAR processing. Ann. Glaciol., 35, 73-78.

Gogineni, S. and 9 others. 2001. Coherent radar ice thickness measurements over the Greenland ice sheet. J. Geophys. Res., 106(D24), 33,761-33,772.

Joughin, I., R. Kwok and M. Fahnestock. 1996. Estimation of icesheet motion using satellite radar interferometry: method and error analysis with application to Humboldt Glacier, Greenland. J. Glaciol., 42(142), 564-575.
Joughin, I., W. Abdalati and M.A. Fahnestock. 2004. Large fluctuations in speed of Jakobshavn Isbræ, Greenland. Nature, 432, 608-610.

Krabill, W. and 9 others. 2000. Greenland Ice Sheet: high-elevation balance and peripheral thinning. Science, 289(5478), 428-430.

Legarsky, J.J., P. Gogineni and T.L. Atkins. 2001. Focused syntheticaperture radar processing of ice-sounder data collected over the Greenland ice sheet. IEEE T. Geosci. Remote, 39(10), 2109-2117.

Peters, M.E., D.D. Blankenship and D.L. Morse. 2005. Analysis techniques for coherent airborne radar sounding: application to West Antarctic ice streams. J. Geophys. Res., 110(B6), B06303. (10.1029/2004JB003222.)

Rignot, E., S. Gogineni, I. Joughin and W. Krabill. 2001. Contribution to the glaciology of northern Greenland from satellite radar interferometry. J. Geophys. Res., 106(D24), 34,007-34,019.

Tee, K.L., and 6 others. 1999. Radar thickness measurement over the southern part of the Greenland Ice Sheet: 1998 results. Radar Systems and Remote Sensing Laboratory Technical Report. 13720-10.

Weidick, A. 1992. Jakobshavn Isbræ area during the climatic optimum. Rapp. Grønl. Geol. Undersøgelse, 155, 67-72. 